Vol. 5 (1996): 503-508.

\title{
Effect of glycine and alanine supplementation on development of cattle embryos cultured in CRIaa medium with or without cumulus cells
}

\author{
Kristiina Bredbacka and Peter Bredbacka \\ Agricultural Research Centre of Finland, Institute of Animal Production, FIN-31600 Jokioinen, Finland, \\ e-mail: kristiina.bredbacka@mtt.fi
}

\begin{abstract}
The effect of alanine $(1 \mathrm{mM})$ and glycine $(10 \mathrm{mM})$ supplementation on bovine embryo development in vitro was investigated. Presumptive bovine zygotes, produced by in vitro maturation and insemination of oocytes, were cultured for $144 \mathrm{~h}$ in CR 1 aa medium in the absence (Experiments 1 and 2) or presence of cumulus cells (Experiment 3). In Experiment 1, the proportion of morulae and blastocysts of cleaved embryos in glycine-supplemented medium was not different from that of the control medium ( $34 \%$ in both media); however, the cell numbers of morulae and blastocysts were significantly higher in the glycine-enriched medium $(69.5$ vs. $53.3, P=0.016)$. In Experiment 2 , addition of alanine did not improve the formation of morulae and blastocysts (13\% vs. $21 \%$ in control medium), and the mean cell numbers in morulae and blastocysts were lower than those in the control group ( 34.3 vs. $68.7, P=0.007$ ). In the presence of cumulus cells, the combined supplementation of glycine and alanine increased the proportion of morulae and blastocysts over that in the control medium $(31 \%$ vs. $14 \%, \mathrm{P}=0.003)$.
\end{abstract}

Key words: bovine, morula, blastocyst, amino acids, in vitro production

\section{Introduction}

Efficient in vitro production of cattle embryos suitable for embryo transfer is hampered by our limited knowledge of the environmental requirements of the preimplantation embryo. At present, only a minority of fertilized oocytes can be cultured to the morula or blastocyst stage (Brackett and Zuelke 1993). In general, the best results have been achieved when co-culture with somatic cells has been used in a complex culture me- dium. The reasons for the beneficial effect of somatic cells are unclear, but it might be attributed to the addition of embryotrophic factors into the medium and/or removal of harmful ingredients from the culture system. Attempts to define such components have had limited success due to the complexity of the medium. Furthermore, some components in the culture medium may be beneficial for somatic cells but detrimental to embryos or vice versa. This could make interpretations of results in the optimization process difficult and perhaps misleading. 


\section{AGRICULTURAL AND FOOD SCIENCE IN FINLAND}

Bredbacka, K. \& Bredbacka, P. Bovine embryo culture in glycine and alanine

The development of chemically defined culture media represents an alternative approach for improving the consistency of culture conditions. Zygotes have been developed to the blastocyst stage in a number of defined media (Pinyopummintr and Bavister 1991, Rosenkrans and First 1991, Seidel et al. 1991, Takagi et al. 1991, Kim et al. 1993, Keskintepe et al. 1995). In some cases bovine serum albumin (BSA) has been used to replace serum. Due to undefined components in BSA, such media may more appropriately be termed semi-defined media.

The amino acid requirement of embryos has been the focus of some recent studies (Bavister and Arlotto 1990, Moore and Bondioli 1993, Liu and Foote 1996, Partridge et al. 1996). Moore and Bondioli (1993) analysed bovine oviductal fluid and concluded that the predominant free amino acids were glycine and alanine. The authors went on to examine the effect of increased concentrations of alanine and glycine on bovine embryo development in BMOC or MBMOC medium. Their results indicated that in the presence of oviductal cells, a combination of glycine and alanine improved embryonic development. Their study was supported by Bondioli et al. (1995), who added high concentrations of glycine and alanine in CR laa-medium to co-culture with beneficial effects.

Our aim here was to further examine the effects of increased levels of alanine and glycine on bovine embryo development with or without cumulus cells. As base medium we used a semidefined medium, the widely applied CR 1 aa (Rosenkrans and First 1991). In addition to morphological evaluation we extended the embryo quality assay by counting nuclei of the embryos.

\section{Material and methods}

\section{In vitro maturation}

Cattle ovaries were obtained from a slaughterhouse and transported to the laboratory at room temperature in $0.9 \% \mathrm{NaCl}$ containing antibiotics. The oocytes were aspirated from follicles (diameter 3-8 $\mathrm{mm}$ ) and only cumulus-surrounded oocytes were accepted. Oocyte-cumulus complexes were washed twice and matured in TCM199 medium supplemented with $0.25 \mathrm{mM}$ sodium pyruvate, $2.0 \mathrm{mM} \mathrm{L}$-glutamine, $100 \mathrm{IU} / \mathrm{ml}$ penicillin, $100 \mu \mathrm{g} / \mathrm{ml}$ streptomycin, $2 \mu \mathrm{g} / \mathrm{ml} \mathrm{FSH}$ (USDA-oFSH-18; USDA, Beltsville, MD, USA), $10 \mu \mathrm{g} / \mathrm{ml} \mathrm{LH} \mathrm{(USDA-bLH-B-6;} \mathrm{USDA,}$ Beltsville, MD, USA), $1 \mu \mathrm{g} / \mathrm{ml}$ estradiol- $17 \beta$ (Sigma, St. Louis, MO, USA), 5\% foetal calf serum and $5 \%$ oestrous cow serum. Forty to fifty oocytes were cultured for $24 \mathrm{~h}$ in a $500-\mu \mathrm{l}$ drop of maturation medium in $5 \% \mathrm{CO}_{2}$ in air at $39^{\circ} \mathrm{C}$.

\section{In vitro fertilization}

After maturation the oocyte-cumulus complexes were inseminated with $1.5 \times 10^{6} / \mathrm{ml}$ of washed frozen-thawed sperm at $39^{\circ} \mathrm{C}$ in $5 \% \mathrm{CO}_{2}$ under oil in $100 \mu \mathrm{l}$ of fert-TALP (Parrish et al. 1988) containing $2 \mu \mathrm{g} / \mathrm{ml}$ heparin and $20 \mu \mathrm{mol} / \mathrm{l}$ penicillamine, $10 \mu \mathrm{mol} / \mathrm{l}$ hypotaurine and $1 \mu \mathrm{mol} / \mathrm{l}$ epinephrine. After $24 \mathrm{~h}$ the cumulus cells were removed by vortexing (Experiments 1 and 2) or were left intact (Experiment 3).

\section{In vitro culture}

After insemination the oocytes were washed in the culture medium CR 1 aa (Rosenkrans and First 1991) and randomized into treatment groups. After $96 \mathrm{~h}$ of culture in $50 \mu \mathrm{l}$-drops of medium without glucose ( $120 \mathrm{~h}$ after insemination), $50 \mu \mathrm{l}$ of fresh culture medium with glucose was added to bring the final glucose concentration to $5.56 \mathrm{mM}$. The embryos were cultured under mineral oil at $39^{\circ} \mathrm{C}$ in a humidified environment of $5 \% \mathrm{CO}_{2}$ in air. The chemicals were obtained from Merck (all salts) or from Sigma (BSA, glutamine, pyruvate, hemi-lactate, amino acids and gentamicin). In Experiment 1, embryo development in the control medium (CR1aa) was compared with that of the control medium sup- 
Vol. 5 (1996): 503-508.

Table 1. Effect of glycine supplementation on development of cattle embryos cultured in CR1aa without cumulus cells.

\begin{tabular}{lcccc}
\hline Treatment & Oocytes & \% Cleaved & $\begin{array}{c}\% \mathrm{M}+\mathrm{B} \\
\text { of cleaved }\end{array}$ & $\begin{array}{c}\overline{\mathrm{x}}( \pm \mathrm{S} . \mathrm{E} .) \\
\text { nuclei in } \mathrm{M}+\mathrm{B}\end{array}$ \\
\hline CRlaa & 180 & 56.7 & 34.3 & $53.3^{\mathrm{a}}( \pm 4.1)$ \\
CRlaa + gly & 176 & 55.1 & 34.0 & $69.5^{\mathrm{b}}( \pm 5.1)$ \\
\hline
\end{tabular}

${ }^{a, b}$ Values with different superscripts differ significantly $(\mathrm{P}<0.05)$

Abbreviations: gly $=$ glycine $(10 \mathrm{mM}), \mathrm{M}+\mathrm{B}=$ morulae+blastocysts

plemented with $10 \mathrm{mM}$ glycine. In Experiment 2 the control medium was compared with the supplementation of alanine ( $1 \mathrm{mM})$. In Experiment 3 , the control medium was compared with supplementation of glycine $(10 \mathrm{mM})$, alanine (1 $\mathrm{mM}$ ) and a combination of these amino acids. Each experiment was repeated at least five times.

After 144 h of embryo culture (Day 7 after insemination) the embryos were examined for appearance and stage of development. The quality of embryos was scored according to Lindner and Wright (1983), however, lower than Grade 2 embryos were not classified as morulae or blastocysts. The cell number was assessed by staining the nuclei of blastomeres with $3 \mu \mathrm{g} / \mathrm{ml}$ Hoechst stain 33258 in $15 \%$ ethanol in PBS for 24 to $48 \mathrm{~h}$ at $+4^{\circ} \mathrm{C}$. After fixation and staining each embryo was individually washed and placed in a $1 \mu \mathrm{l}$ drop of PBS into a 10 to $15 \mu \mathrm{l}$ drop of a mixture of glycerol and water (5:1) on a glass slide. The embryo was then overlaid with a coverslip and the nuclei were counted under a Leitz Dialux 20 fluorescence microscope using the Leitz A filter block.

\section{Statistical analysis}

Proportions (cleaved embryos of inseminated oocytes, and Grade 1 and Grade 2 compacted morulae and blastocysts of cleaved embryos) were compared by $\chi^{2}$ analysis. The cell numbers of embryos of transferable quality (Grade 1 and
Grade 2 morulae and blastocysts) were compared using the GLM program of SAS (SAS Institute, Cary, NC, USA). The effect of replicates was included in the model.

\section{Results}

\section{Experiment I}

The addition of glycine $(10 \mathrm{mM})$ had no effect on cleavage rate or development to the morula/ blastocyst stage (Table 1). However, the supplementation increased the cell proliferation in morulae and blastocysts when compared with the controls $(\mathrm{P}=0.016)$. The cell number in morulae and blastocysts in glycine-supplemented CRlaa medium was $69.5( \pm 5.1)$, which is significantly higher $(\mathrm{P}=0.016)$ than that in the control CR1 medium, $53.3( \pm 4.1)$.

\section{Experiment 2}

Supplementation of CR 1 aa medium with alanine did not significantly affect cleavage rate or development to the morula/blastocyst stage (Table 2). However, cell numbers of morulae and blastocysts were significantly lower $(P=0.007)$ in alanine-supplemented medium than in the controls (34.4 and 68.7, respectively). 
Bredbacka, K. \& Bredbacka, P. Bovine embryo culture in glycine and alanine

Table 2. Effect of alanine supplementation on development of cattle embryos cultured in CR1aa without cumulus cells.

\begin{tabular}{|c|c|c|c|c|}
\hline Treatment & Oocytes & $\%$ Cleaved & $\begin{array}{c}\% \mathrm{M}+\mathrm{B} \\
\text { of cleaved }\end{array}$ & $\begin{array}{c}\overline{\mathrm{x}}( \pm \text { S.E. }) \\
\text { nuclei in } \mathrm{M}+\mathrm{B}\end{array}$ \\
\hline CRlaa & 185 & 54.6 & 20.8 & $68.7^{a}( \pm 8.6)$ \\
\hline CRlaa + ala & 185 & 55.7 & 12.6 & $34.4^{\mathrm{b}}( \pm 5.8)$ \\
\hline
\end{tabular}

$a, b$ Values with different superscripts differ significantly $(\mathrm{p}<0.01)$

Abbreviations: ala $=$ alanine $(1 \mathrm{mM}), \mathrm{M}+\mathrm{B}=$ morulae+blastocysts.

Table 3. Effect of supplementation of glycine and/or alanine on development of cattle embryos cultured in CRlaa in coculture with cumulus cells.

\begin{tabular}{lcccc}
\hline Treatment & Oocytes & \% Cleaved & $\begin{array}{c}\text { \% M+B } \\
\text { of cleaved }\end{array}$ & $\begin{array}{c}\text { Nuclei in M+B } \\
\text { (least square means) }\end{array}$ \\
\hline CR1aa+CC & 182 & 55.5 & $13.9^{\mathrm{a}}$ & 94.1 \\
CR1aa+CC+gly & 182 & 58.8 & $20.6^{\text {ab }}$ & 115.7 \\
CRlaa+CC+ala & 178 & 53.4 & $23.2^{\text {ab }}$ & 105.5 \\
CRlaa+CC+gly+ala & 177 & 57.6 & $31.4^{\text {b }}$ & 95.3 \\
\hline
\end{tabular}

a,b Values with different superscripts differ significantly $(\mathrm{P}<0.05)$

Abbreviations: $\mathrm{CC}=$ cumulus cells, $\mathrm{gly}=$ glycine $(10 \mathrm{mM})$, ala $=$ alanine $(1 \mathrm{mM}), \mathrm{M}+\mathrm{B}=$ morulae + blastocysts.

\section{Experiment 3}

As shown in Table 3, in cumulus cell co-culture the percentage of transferable embryos (Grade 1 and Grade 2 morulae and blastocysts) was significantly higher $(\mathrm{P}=0.003)$ in $\mathrm{CR} 1$ aa medium supplemented with both glycine $(10 \mathrm{mM})$ and alanine $(1 \mathrm{mM})$ than in the absence of supplementation. Supplementation of only one of the amino acids gave morula/blastocyst rates intermediate between the nonsupplemented and double-supplemented group (N.S.). No effects of the amino acid supplementations on cleavage rate or cell number were observed.

\section{Discussion}

In our study the in vitro production of cattle morulae and blastocysts in CR 1 aa medium was increased by the combined supplementation of glycine and alanine when a cumulus cell co-culture approach was used. The effect was due not to an increase in cleavage rate but to an increase in the development of cleaved zygotes. This increase was statistically significant only when both of these amino acids were added to the culture medium. When either of the amino acids was used alone, the proportion of morulae and blastocysts was between that of the nonsupplemented treatment and the treatment in which both amino acids were added. Although the combined addition of these compounds did not significantly improve the morphological development when compared with supplementation of either glycine or alanine alone, a synergistic effect might be implicated.

The study of Moore and Bondioli (1993) presents a rather similar picture. These authors used a modified Brinster's oviduct culture medium and a one-day-longer culture period (7 days). In co-culture with oviduct cells, they re- 


\section{AGRICULTURAL AND FOOD SCIENCE IN FINLAND}

Vol. 5 (1996): 503-508.

ported the highest rate of morula/blastocyst development when alanine and glycine were used in combination. However, alanine alone was not sufficient to improve development. Bondioli et al. (1995) demonstrated increased development to the expanded blastocyst stage when CR1aa medium supplemented with foetal calf serum and buffalo rat liver cells was used with a combination of glycine and alanine. Employing a complex medium (TCM199), Shi et al. (1995) showed that supplementation of a combination of alanine $(2.5 \mathrm{mM})$ and glycine $(12.5 \mathrm{mM}) \mathrm{im}$ proved blastocyst development in a 7 day coculture with a granulosa cell monolayer when the serum concentration was $10 \%$; at a lower serum concentration $(2.5 \%)$, no effect of the added amino acids was found.

We did not observe an effect of glycine or alanine supplementation on morula/blastocyst development rate in a cell-free culture system. However, glycine supplementation improved the quality of morulae and blastocysts as measured by number of nuclei. By the same criteria, alanine supplementation alone diminished the quality of morulae and blastocysts. Using cellfree culture with CR2 as the base medium - a very similar culture system to the one used here - Suh et al. (1995) observed a higher proportion of blastocyst formation with glycine supplementation than with both glycine and alanine supplementation. Thus, alanine would seem to have a favourable effect on bovine embryo development in co-culture with somatic cells, but a detrimental effect in a cell-free system. It is therefore possible that, in a co-culture, alanine improves embryo development only indirectly, perhaps by altering the function of somatic cells, as suggested by Moore and Bondioli (1993). Glycine, on the other hand, may have both direct and indirect effects on bovine development.

Although our experiments were not designed to compare the cell-free system with the co-culture system, a comparison of the number of nuclei seems to indicate that the co-culture system better supports cell proliferation in morulae and blastocysts. However, the proportion of morulae and blastocysts does not appear to be significantly affected by the co-culture. The cell count may be an important parameter in the quality assay of different embryo culture systems.

In conclusion, we found that the combined use of glycine and alanine in a co-culture system with cumulus cells is promotes bovine embryo development, confirming previous reports. Furthermore, cell numbers in morulae and blastocysts were increased by the addition of glycine and decreased by the addition of alanine in a cell-free culture system.

Acknowledgements. The authors are grateful to T.-M. Nieminen and J. Peippo for technical assistance. FSH and LH were kindly provided by D.J. Bolt (USDA Animal Hormone Program, Beltsville, MD, USA).

\section{References}

Bavister, B.D. \& Arlotto, T. 1990. Influence of single amino acids on the development of hamster one-cell embryos in vitro. Molecular Reproduction and Development 25: 45-51.

Bondioli, K.R., Hawk, H.W. \& Wall, R.J. 1995. Effect of glycine and alanine on co-culture of bovine blastocysts. Theriogenology 43: 170. (Abstract).

Brackett, B.G. \& Zuelke, K.A. 1993. Analysis of factors involved in the in vitro production of bovine embryos. Theriogenology 39: 43-64.

Keskintepe, L., Burney, C.A. \& Brackett B.G. 1995. Production of viable blastocysts in defined in vitro conditions. Biology of Reproduction 52: 1410-1417.
Kim, J.-H., Niwa, K., Lim, J.-K. \& Okuda, K. 1993. Effects of phosphate, energy substrate, and amino acids on development of in vitro-matured, in vitro-fertilized bovine oocytes in a chemically defined, protein-free culture medium. Biology of Reproduction 48: 1320-1325.

Lindner, G.M. \& Wright, R.W., Jr. 1983. Bovine embryo morphology and evaluation. Theriogenology 20: 407-416. Liu, Z. \& Foote, R.H. 1996. Effects of amino acids on development of IVM/IVF bovine embryos in a simple protein-free medium. Theriogenology 45: 169. (Abstract). Moore, K. \& Bondioli, K.R. 1993. Glycine and alanine supplementation of culture medium enhances development of in vitro matured and fertilized cattle embryos. 


\title{
AGRICULTURAL AND FOOD SCIENCE IN FINLAND
}

Bredbacka, K. \& Bredbacka, P. Bovine embryo culture in glycine and alanine

Biology of Reproduction 48: 833-840.

Parrish, J.J., Susko-Parrish, J., Winer, M.A. \& First, N.L. 1988. Capacitation of bovine sperm by heparin. Biology of Reproduction 38: 1171-1180.

Partridge, R.J., Pullar, D., Wrathall, A.E. \& Leese, H.J. 1996. Consumption of amino acids by in vivo and in vitro-derived bovine embryos. Theriogenology 45 : 181. (Abstract).

Pinyopummintr, T. \& Bavister, B.D. 1991. In vitro-matured/in vitro-fertilized bovine oocytes can develop into morulae/blastocysts in chemically defined, protein-free culture media. Biology of Reproduction 45: 736-742.

Rosenkrans, C.F. \& First, N.L. 1991. Culture of bovine zygotes to the blastocyst stage: effect of amino acids and vitamins. Theriogenology 35: 266. (Abstract).

Seidel, G.E., Jr, Glass, T. \& Olson, S.E. 1991. Culture of 1 -cell bovine embryos to blastocysts in chemically defined media. Biology of Reproduction 44, Supplement 1: 155. (Abstract).

Shi, D.S., Tan, S.J., Huang, F.L. \& Lu, K.H. 1995. Effects of glycine and alanine on the in vitro development of early bovine embryos derived from IVM/IVF. Theriogenology 43: 323. (Abstract).

Suh, T.K., White, K.L., Bunch, T.D., Spendlove, R. \& Wilkinson, R. 1995. Effect of glycine, alanine and calf plasma in serum free culture medium on bovine embryonic development in vitro. Theriogenology 43: 328. (Abstract).

Takagi, Y., Mori, K., Tomizawa, M., Takahashi, T., Sugawara, S. \& Masaki, J. 1991. Development of bovine oocytes matured, fertilized and cultured in a serum-free, chemically defined medium. Theriogenology 35 : 11971207.

\section{SELOSTUS}

\section{Glysiinin ja alaniinin vaikutus CRIaa-liuoksessa viljeltyyn kumulussolullisen ja -soluttoman naudanalkion kehitykseen}

\author{
Kristiina Bredbacka ja Peter Bredbacka \\ Maatalouden tutkimuskeskus
}

Glysiinin $(10 \mathrm{mM})$ ja alaniinin $(1 \mathrm{mM})$ vaikutusta naudan alkion varhaiskehitykselle tutkittiin kolmessa viljelykokeessa. Kumulussoluttomia alkioita viljeltiin hedelmöityksen jälkeen CR 1aa-liuoksessa, johon oli lisätty glysiiniä (koe 1) ja alaniinia (koe 2). Kokeessa 3 käytettiin alkioita, joista ei poistettu kumulussoluja ja ne jaettiin neljään eri viljelyliuokseen: CR 1 aa + glysiini (10 mM), CR1 aa + alaniini (1 mM), CR1aa + glysiini + alaniini sekä kontrolliliuos, joka oli kaikissa kokeissa CR1aa. Alkioita viljeltiin yhteensä kuusi päivää. Neljäntenä päivänä viljelytippoihin lisättiin tuoretta viljelyliuosta ja glukoosia (lopullinen pitoisuus $5,56 \mathrm{mM}$ ). Viljelyn päätyttyä alkiot luokiteltiin kehitysvaiheen mukaisesti ja niiden solujen lukumäärä laskettiin värjäämällä fiksoitujen alkioiden tumat Hoechst-värillä.
Kokeessa 1 glysiinin lisäyksellä ei ollut vaikutusta alkioiden kehittymiseen morula/blastokystivaiheeseen. Morula/blastokystialkioiden solujen lukumäärä oli kuitenkin merkitsevästi korkeampi glysiiniryhmässä $(69,5)$ kuin kontrolliryhmässä $(53,3)$.

Kokeessa 2 alaniinilla ei todettu merkitsevää vaikutusta morula/blastokystien määrään, mutta morula/blastokystivaiheen alkioiden solujen lukumäärä oli merkitsevästi alhaisempi alaniiniryhmässä $(34,4)$ kuin kontrolliryhmässä $(68,7)$.

Kumulussolullisia alkioita viljeltäessä (koe 3) aminohappojen lisäyksellä ei havaittu vaikutusta solujen lukumääriin. Sen sijaan morula/blastokystivaiheen alkioita saatiin kontrolliryhmään verrattuna merkitsevästi enemmän kun viljelyliuokseen lisättiin sekä glysiiniä että alaniinia. 